\title{
PERAN KONSELOR DALAM MENGANTISIPASI KRISIS MORAL ANAK DAN REMAJA MELALUI PEMANFAATAN MEDIA "BARU"
}

\author{
Mochamad Nursalim \\ Universitas Negeri Surabaya
}

\begin{abstract}
Abstrak
Kehadiran media "baru" diantaranya handphone, internet dan sosial media telah membuat perubahan besar dalam penyampaian pesan dan pola komunikasi pada anak dan remaja. Di sisi lain media dapat menjadikan anak dan remaja kehilangan jati diri, dan memperburuk moralitas anak dan remaja. Berdasarkan studi awal, diperoleh data efek negatif yang muncul akibat perkembangan media "baru" diantaranya adalah anak kecanduan game online, kecanduan bermedsos, waktu anak habis untuk bermain handphone, anak menjadi korban pelecehan seksual melalui media, munculnya konflik akibat postingan di media sosial, dan sebagainya. Beberapa peran yang dapat dilakukan konselor sekolah untuk mengantisipasi munculnya krisis moral pada anak dan remaja adalah; 1) meningkatkan kemampuan dan ketrampilan dalam memanfaatkan kehadiran "media baru", 2) bekerja sama dengan wali kelas dan orang tua dalam memonitor penggunaan media baru, baik berupa frekuensi, durasi maupun isi, 3) Mengedukasi penggunaan internet positif, 4) mempelajari strategi konseling untuk menangani masalah yang muncul diantaranya, kecanduan game onlie, pornografi, bullying dan ujaran kebencian.
\end{abstract}

Kata Kunci: Peran, Konselor, Krisis Moral, Media "Baru"

\section{Abstract}

The presence of "new media" such as mobile phones, internet and social media has made major changes in the delivery of messages and communication patterns in children and adolescents. On the other hand, media can make children and teenagers lose their identity, and worsen the morality of children and adolescents. Based on preliminary studies, the negative effects of the "new media" are among the addicted children of online games, addicted to social media, children's time to play mobile phones, children become victims of sexual harassment through the media, the emergence of conflict due to postings on social media, and so on. Some of the roles that school counselors can do to anticipate the emergence of a moral crisis in children and adolescents are; 1) improving skills in utilizing the presence of "new media"; 2) working with teachers and parents in monitoring the use of "new media", in the form of frequency, duration and content; 3) educating positive internet usage; 4) studying counseling strategies to deal with emerging problems, addiction to onlie games, pornography, bullying and hate speech.

Keywords: Role, Counselor, Moral Crisis, "Baru" Media

\section{PENDAHULUAN}

Pesatnya perkembangan teknologi dalam dekade terakhir membawa dampak ke berbagai sektor. Salah satunya media, di mana penyampaian dan pertukaran pesan dihadirkan melalui teknologi. Komunikasi massa adalah proses produksi dan distribusi pesan secara luas dan berkelanjutan oleh institusi (organisasi) berlandaskan teknologi dalam masyarakat industri. Tidak dipungkiri bahwa teknologi membuat komunikasi semakin mudah dilakukan. Bersamaan dengan perkembangan teknologi, hadir juga media yang diberi nama media "baru" (new media). Munculnya new media dipengaruhi oleh Computer Mediated Comunication (CMC). CMC adalah segala bentuk komunikasi antar individu, individu dengan kelompok melalui komputer dalam suatu jaringan internet. Blog, Myspace, facebook, youtube, bbm, twitter dan bentuk lain merupakan bentuk dari CMC. Situs-situs tersebut memungkinkan penggunanya berbagi informasi dalam bentuk teks, gambar, audio dan video.
Media dan teknologi baru telah memberikan cara baru bagi kita untuk memperoleh informasi dan gagasan, cara baru untuk berinteraksi dengan teman dan orang asing, dan cara baru untuk mempelajari dunia, identitas kita dan masa depan (Gamble, 2005). Jutaan orang saat ini berinteraksi melalui apa yang disebut cyberspace, yaitu sebuah dunia yang terhubung melalui HP, dan internet.

Melalui media "baru", social media diperkenalkan. Social media menjadi sebuah media penting karena kehadirannya membuat perubahan besar dalam penyampaian pesan. Komunikasi yang dilakukan saat ini sering menggunakan internet melalui social media.

Media sosial mempunyai fungsi positif, antara lain; a) memberikan informasi tentang peristiwa dan kondisi masyarakat; memudahkan inovasi, adaptasi dan kemajuan, b) memberi informasi yang bersifat menjelaskan, menafsirkan, mengomentari makna peristiwa dan informasi; melakukan sosialisasi dan 
membentuk konsensus. c) memberi informasi tentang hal yang berkesinambungan meliputi peningkatan dan pelestarian nilai-nilai; mengekpresikan budaya dan pengakuan budaya. d) memberikan hiburan untuk meredakan ketegangan sosial dan sarana relaksasi. e) memobilisasi masyarakat dalam bidang pilitik dan pembangunan (McQuil, 1996).

Kehadiran media "baru", juga telah mempengaruhi kehidupan anak dan remaja. Melalui media baru, anak dan remaja dapat mengalami dan belajar tentang berbagai aspek, bahkan memperoleh ide-ide tentang dunia melalui media. Di sisi lain media dapat menjadikan anak dan remaja kehilangan jati diri, dan memperburuk moralitas anak dan remaja. Berdasarkan studi awal, diperoleh data efek negatif yang muncul akibat perkembangan media "baru" diantaranya adalah anak kecanduan game online, kecanduan bermedsos, waktu anak habis untuk bermain hp, anak menjadi korban pelecehan seksual melalui media, munculnya konflik akibat postingan di media sosial, dan sebagainya. Demikian juga, Tradisi diskusi, meneliti, membaca, berorganisasi hingga saling berlomba dalam prestasi seakan lenyap di telan peradaban. Anak dan remaja masa kini lebih banyak disibukkan oleh halhal hedonisme yang hanya mementingkan dirinya sendiri. Anak dan remaja masa kini seolah sudah kehilangan daya kekritisannya

Guru BK sebagai salah satu pendidik yang berfungsi sebagai purifier "penjernih" perlu memahami dan menguasai kehadiran berbagai media "baru", serta dapat memanfaatkan media baru tersebut untuk mendukung pelaksanaan bimbingan dan konseling. Media baru bagai dua sisi mata uang memiliki peluang untuk mengarahkan ke kebaikan dan peluang ke arah keburukan. Tulisan ini akan mengupas Peran konselor dalam Mengantisipasi Krisis Moral Anak dan Remaja melalui Pemanfaatan Media "Baru"

\section{METODOLOGI}

\section{Ancaman Krisis Moral Remaja Di Era Global}

Konsep dan standar baik buruk, patas dan tidak pantas telah berkembang sangat pesat sejajar dengan semakin majunya proses industrialisasi dan urbanisasi yang ditopang dengan cepatnya perkembangan teknologi informasi. Kesemuanya itu menjadi kesatuan yang tak terpisahkan dalam arus globalisasi. Globalisasi hanyalah ujung yang nampak, permukaan gunung es dalam samudera yang menyembul, namun di bawahnya terdapat sesuatu yang jauh lebih rumit dan besar, lebih berpengaruh dalam berbagai sisi kehidupan masyarakat, tergabung dalam arus besar industrialisasi dan kapitalisasi. Semua masyarakat modern, terutama sekali di negara Barat, secara universal terkondisi menonjolkan Prestasi individual. Setiap orang didorong untuk mendapatkan sukses materiil. Akan tetapi masyarakat tidak selalu bisa menyediakan sarana dan fasilitas yang sama bagi setiap orang guna mencapai sukses materiil ini. Dalam mengejar kesuksesan ini menjadikan orang-orang bergerak di tengah struktur masyarakat yang terpecah-pecah, yang kemudian berubah menjadi kelompok atomistis (mikro) yang sangat mobil sifatnya. Dalam situasi demikian banyak orang yang mengalami depersonalisasi, di sisi lain kontrol sosial dan tradisi banyak kehilangan pengaruhnya. Sebaliknya, nafsu manusia modern untuk berkompetisi guna mencapai sukses materiil semakin menanjak, persaingan semakin sengit. Kondisi demikian jelas bisa memberikan tekanan batin pada setiap anggota masyarakat,banyak orang mengalami kekecewaan dan frustasi, termasuk di dalamnya para remaja.

\section{Faktor-faktor Penyebab krisis Moral}

Ada beberapa faktor penyebab krisis moral remaja, antara lain yaitu;

a. Tersebar luasnya pandangan materialistis tanpa spiritualitas, ukuran kesuksesan lebih di ukur pada kesuk-sesan materiil dan mengenyampingkan moralitas.

b. Konsep moralitas kesopanan menjadi longgar karena terpengaruh budaya barat akibat dari mudahnya mencari informasi melalui ICT.

c. Budaya global menawarkan kenikmatan semu melalui $3 \mathrm{~F}$ : food, fashion dan fun.

d. Tingkat persaingan semakin tinggi, karena terbukanya sekat lokal dan kebanyakan bersifat online.

e. Masyarakat lebih bersifat individualistis dan kurang peduli dengan lingkungannya, sehingga kontrol moral terutama pada remaja menjadi rendah.

f. Keluarga kurang dapat memberi pengarahan, karena masing-masing orang tua sudah mempunyai kesibukannya sendiri atau bahkan broken home.

g. Sebagian besar sekolah tidak sepenuhnya dapat mengontrol perilaku siswa, karena keterbatasan waktu, sumber daya dan sumber dana ataupun kurang menekankan pentingnya moralitas.

\section{Bentuk-bentuk krisis Moral Remaja}

Penyimpangan, krisis, kenakalan atau bahkan kejahatan remaja selalu berlangsung dalam konteks antar personal dan sosio kultural. Kenakalan remaja dari sisi jenisnya setidaknya dapat dibagi menjadi empat macam yaitu:

a. Individual, kenakalan yang secara personal atau individualnya dengan ciri khas jahat (tidak normal) yang disebabkan oleh predisposisi dan 
kecenderungan penyimpangan prilaku yang diperkuat dengan stimuli sosial dan kondisi kultural,

b. Situasional, kenakalan yang dilakukan oleh anak normal, namun mereka banyak dipengaruhi oleh berbagai kekuatan situasional, stimuli sosial dan tekanan lingkungan yang 'menekan dan memaksa'.

c. Sistematis, kenakalan yang disistematisir dalam bentuk suatu organisasi struktural yaitu 'gang'. Kumpulan tingkah laku tersebut disertai pengaturan, status formal, peranan tertentu, nilai-nilai rite-rite, dan juga kebanggan, bahkan tidak jarang mereka menghasilkan bahasa-bahasa khas.

d. Kumulatif, kenakalan yang terus menerus dilakukan sehingga bersifat kumulatif, ditiru diberbagai tempat dan menyebar luas di tengah masyarakat dan bisa mengakibatkan disintegrasi sosial. Kumulatif bisa bersifat individu ataupun kelompok, pada tingkat akumulasi yang tinggi anak sudah sulit kembali pada prilaku yang sesuai dengan norma sosial yang ada.

Adapun dari sisi bentuknya, setidaknya bisa dalam berbagai bentuk antara lain:

a. Kenakalan yang menimbulkan korban fisik pada orang lain: perkelahian, perkosaan, perampokan,pembunuhan, dan lain-lain.

b. Kenakalan yang menimbulkan korban materi: perusakan, pencurian, pencopetan, pemerasan, dan lain-lain.

c. Kenakalan sosial yang tidak menimbulkan korban di pihak orang lain: pelacuran, penyalahgunaan obat.

d. Kenakalan yang melawan status, misalnya mengingkari status anak sebagai pelajar dengan cara membolos, mengingkari status orang tua dengan cara minggat dari rumah atau membantah perintah mereka

e. Kenakalan remaja non-kriminal, yang mengalami masalah jenis ini cenderung tertarik pada kesenangankesenangan yang sifatnya menyendiri, apatis terhadap kegiatan

\section{Pengaruh Media "Baru" Terhadap Moral Dan Perilaku Remaja}

Tren zaman sekarang masyarakat lebih memilih segala sesuatu yang lebih praktis. Dengan adanya media teknologi yang kian semakin maju, manusia semakin dimanjakan dalam beraktifitas sehari-hari, demi mendapakan hiburan maupun informasi. Informasi yang dimaksud yaitu berupa informasi politik, bisnis, budaya, pendidikan, dan lain-lain. Salah satu media yang sangat berpengaruh terhadap perubahan serta pembentukan pola pikir, perilaku dan gaya hidup masyarakat adalah media online (internet). Untuk lebih jelasnya, alangkah baiknya penulis menyajikan data terkait media internet secara global maupun di Indonesia.

Berdasarkan survei pada The Population Reference Bureau (PRB) 4 Agustus 2016 bahwa jumlah penduduk bumi mencapai 7.4 miliar. Sedangkan pengguna internet dunia mencapai $50.1 \%$ yakni 3.6 miliar. Sedangkan jika melihat jumlah penduduk indonesia sebagaimana yang terhimpun dalam We are social menyatakan bahwa total populasi Indonesia mencapai 259.1 juta, sedangkan pengguna internet Indonesia mencapai 88.1 juta yang berbanding lurus dengan pengguna media social yakni mencapai 79 juta. Dengan rincian penetrasinya yaitu untuk wilayah Jawa-Bali mencapai 52 juta, Sumatra mencapai 18.6 juta, Kalimantan 4.2 juta, Sulawesi 7.3 juta dan Nusa Tenggara-Papua-Maluku mencapai 5.9 juta pengguna internet.

Data "Digital in 2016" yang dirilis oleh We Are Social juga menampilkan berapa lama orang Indonesia rata-rata menggunakan internet tiap harinya serta platform media yang paling popular diindonesia. Dalam penggunaan media masyarakat Indonesia menggunakan komputer tidak terlepas lebih dari 4 jam, sedangkan penggunaan mobile tidak terlepas lebih dari 3 jam, dan penggunaan media social tidak kurang 2 jam, sedangkan televisi tidak lebih dari 2 jam pula.

Mobile merupakan media yang tidak pernah terlepas setiap waktu dari tangan masyarakat Indonesia. Namun untuk mengetahui prioritas penggunaan mobile itu sendiri perlu kita ketahui bahwa ternyata $27 \%$ hanya untuk sms dan calling, 22\% digunakan untuk nonton video, $19 \%$ digunakan games, $20 \%$ digunakan bangking dan 22\% digunakan untuk map. Artinya bahwa masyarakat Indonesia masih tidak produktif dalam menggunakan mobile. Sehingga hal ini butuh kesadaran untuk meningkatkan produktifitas penggunaan media baik itu media social (BBM, facebook dll), media online (internet), media elektronik (televisi dan mobile).

Kemutakhiran teknologi, khususnya internet, terkadang disalahgunakan dalam pemakaiannya. Berdasarkan hasil survei yang dilakukan Komisi Perlindungan Anak Indonesia (KPAI) pada tahun 2013 bahwa $97 \%$ pelajar SMP dan SMA diindonesia mengakses dan menonton video porno. Survey ini dilakukan dengan objek di dua belas kota besar di Indonesia yang terdiri dari 4500 pelajar SMP dan SMA. Sementara itu penelitian yang dilakukan oleh Yayasan Anak di Jabodetabek menunjukkan sebanyak $85 \%$ anak usia 9-15 tahun pernah mengakses pornografi. Sehingga saat itu pengguna internet di Indonesia mencapai 63 juta, dan $80 \%$ penggunanya berusia 15-30 tahun.

Sementara pada tahun 2015, ketua Komnas perlindungan anak mengatakan pula bahwa dari 88.1 juta jumlah pengguna internet, $35 \%$ atau 45 juta pengakses 
situs porno yang rata-rata terdiri dari berusia dibawah umur 50. Sejalan dengan itu menteri pemberdayaan perempuan dan perlindungan anak, Yohana Susana Yembise mengatakan bahwa menurut data unit kejahatan cyber Mabes Polri ada 25 ribu anak yang menonton pornografi per hari. Dan Tercatat $37 \%$ dari 4 juta web address merupakan situs yang berbasis pada konten pornografi.

Dari data diatas, hal ini menjadikan Indonesia sebagai pengakses situs porno peringkat ke 3 terbesar setelah India yang pada tahun sebelumnya menempati peringkat ke 4 . Artinya bahwa Indonesia memiliki potensi menjadi peringkat Negara berprestasi negatif terbesar pada tahun-tahun yang akan datang.

Menurut Dirjen Aplikasi Informatika, Ashwin Sasongko, banyaknya angka tersebut salah satunya juga disebabkan oleh media dunia internet. Media menggambarkan bagaikan dua mata pisau yang bisa memberikan dampak yang positif bagi pengguna, namun disisi lain juga memberikan dampak yang negatif, merusak pola pikir dan tindak penggunanya.

Permasalahan ini memang sudah ditangani oleh pemerintah sebagaimana diatur pada UU Nomor 11 Tahun 2008 Tentang Informasi Dan Transaksi Elektronik dalam perspektif penanggulangan penyalahgunaan internet. Hal itu dibuktikan dengan program penanggulangan Cyberporn dengan menghapus jutaan situs-situs porno setiap harinya.

Namun hal tersebut tidak menutut kemungkinan terlepas dari pengawasan pemerintah, mengingat pergulatan media internet dengan akses yang sangat luas menghubungkan seluruh dunia 24 jam. Maka disini juga dibutuhkan kesadaran individu-individu masyarakat dan terutama para orang tua dalam mengawasi anak-anaknya dari penggunaan media.

Dunia advertisement atau periklanan pun juga mampu menanamkan sebuah budaya. Sebagai contoh, iklan shampoo, mengambarkan ketombe atau rambut rontok sebagai sesuatu yang sangat menakutkan. Disamping itu pula sebagian besar iklan-iklan memuat unsur-unsur pengundang syahwat (beautiful women) seakan-akan tanpa diaktori seorang wanita cantik iklan tersebut tidak akan perfect.

Disisi lain maraknya dunia music mendasari para remaja untuk mengonsumsi music baik secara lansung di TKP (konser show), melalui MP3, maupun video klib. Di mana video-vidio tersebut memuat unsur-unsur konten hedonis dan materialistik serta pergaulan bebas. Inilah yang memberikan efek bagi sebagian kalangan terutama remaja yang kehilangan moralitas serta jati diri agama dan bangsanya.

Peran media dalam sebagai pemberi informasi berkaitan dengan adanya perubahan sikap masyarakat.
Media dapat menciptakan perubahan sikap yang diinginkan dari penyebarluasan informasi. Media menghasilkan opini masyarakat yang terimbas melalui sikap masyarakat itu sendiri. Perubahan sikap yang lebih baik atau lebih tidak baik ditentukan oleh media sendiri. Media dapat menghapus kekerasan dan diskriminasi atau malah menumbuhsuburkan sikap tersebut dalam masyarakat.

Namun apapun dampak dari peran media massa, keberadaan media komunikasi ini menjadi suatu kebutuhan yang tidak bisa dilepaskan dari manusia. Media massa merupakan salah satu bentuk sarana komunikasi yang paling efektif dewasa ini di dalam mensosialisasikan dan mendesiminasikan berbagai informasi ke masyarakat luas. Media massa cetak dan elektronik menjadi salah satu ujung tombak bagi percepatan penyebaran informasi bagi masyarakat, apalagi pada era globalisasi sekarang ini, ketika batasan-batasan dan hambatan-hambatan geografis, iklim/cuaca, dan lain-lain tidak menjadi penghalang berarti bagi tersebarnya informasi ke khalayak ramai (masyarakat). Efektifitas serta peranannya yang begitu hebat menjadikan media massa menjadi salah satu komponen penting bagi pembentukan kepribadian masyarakat, serta perilaku dan pengalaman kesadaran masyarakat. Oleh karena itu pulalah banyak kelompok masyarakat yang berupaya menjadikan media massa sebagai sarana propaganda ide, cita-cita, nilai dan norma yang mereka ingin bentuk/ciptakan. Tinggal bagaimana pemilik media massa untuk lebih bijaksana dalam menjalankan peran media massa secara nyata.

Media massa memiliki 3 (tiga) peran sebagai pelopor perubahan. Peran media dalam mendorong perubahan sosial masyarakat sebagai perubah pola pikir masyarakat, sebagai perubah sikap masyarakat dan sebagai perubah budaya materi masyarakat. Ketiga aspek perubahan sosial ini akan kearah yang baik apabila masyarakat sudah siap mental dan menerima perubahan tersebut sebagai pencerahan pengetahuan dan kemajuan hidup tanpa kehilangan norma dan moral. Apabila tidak maka akan menimbulkan krisis moral dalam masyarakat.

Tanpa disadari peran media telah membawa masyarakat masuk ke dalam pola budaya baru dan mulai menentukan pola pikir serta perilaku masyarakat. Sebagaimana pandangan Turkle bahwa media bukan hanya sekedar tool belaka tetapi juga bagian dari kehidupan sosial dan psikologis yang mempengaruhi alam bawah sadar serta mengatalisasi cara hidup. Sehingga peran serta dampak yang ditimbulkan oleh media tidak hanya sekedar mengeser nilai-nilai sosial, budaya dan agama, tetapi lebih dari itu yaitu membentuk budaya baru (tren) dalam kehidupan masyarakat. Budaya inilah yang dikenal dengan istilah budaya popular (popular culture) 
yang merupakan hasil dari peran destruktif-konstruktif media.

Media juga berperan dalam pengusungan ideologi Barat Post-Modern. Adapun ideologi tersebut sebagai berikut.

\section{Hedonisme}

Hedonisme merupakan pandangan hidup yang menganggap kesenangan dan kenikmatan sebagai tujuan hidup. Hedonism is considered a lifestyle in which pleasure and happiness are the ultimate goals in life. Hal ini sesuai dengan falsafah hedonisme yang mengatakan bahwa kesenangan atau kenikmatan merupakan realitas hidup yang tidak perlu dihindarkan dan setiap orang suka merasakan akan hal itu. Gaya hidup hedonis merupakan budaya yang diciptakan oleh media sekuler melalui acaraacara entertainment yang bersifat destruktif. Dalam hal ini, media sekuler turut menciptakan kebutuhan semu dan instan yang membenarkan kenikmatan.

\section{Konsumerisme}

Bila konsumsi adalah sebuah tindakan (an act), maka konsumerisme adalah sebuah cara hidup ( $a$ way of life) atau sebuah expresi budaya dan manifestasi dari tindakan konsumsi. Consumerism is the cultural expression and manifestation of the apparently ubiquitous act of consumtion.

Konsumerisme merupakan ideologi yang menjadikan seseorang yang menjalankan proses pemakaian barang-barang secara berlebihan secara sadar yang berkelanjutan. Hal ini menjadikan manusia menjadi pecandu dari suatu produk, sehingga ketergantungan tersebut tidak dapat atau susah untuk dihilangkan. Dan selanjutnya sifat konsumtif yang ditimbulkan akan menjadikan penyakit jiwa yang tanpa sadar menjangkit manusia dalam kehidupannya.

Ideologi konsumerisme ini bekerja dengan cara seperti "ideologi roman". Atau pencarian yang tiada akhir dan pergerakan hasrat metonimik yang tidak ada habisnya, seperti dalam menggunakan barang sesuai dengan mengikuti tren yang berkembang. Hal inilah yang merupakan buah hasil dari sajian media sekuler berupa iklan-iklan diberbagai laman media baik cetak, elektronik maupun online.

\section{Materialisme}

Materialisme adalah pandangan hidup yang mencari dasar segala sesuatu berlandaskan kebendaan semata, dengan mengesampingkan segala sesuatu yang bersifat non materi seperti jiwa, roh, cinta.

Materialism is a dirty word among the young, who aspire to be idealistic in their though and behavior. Materialism is what happen to you when you abandon your ideals and sell out. Never mind that the more money people make, the more likely they are think of themselves as idealists.
Para materialis berpegang kepada falsafah hidup yang tidak menghormati pandangan religius tentang hidup, kebebasan serta martabat manusia karena mereka terlalu mengukur segala sesuatu dengan berdasarkan pemilikan materi, bahkan penghormatan kepada seseorang pun didasarkan pada kekayaan materi yang dimilikinya. Ideologi inilah yang mengakar pada pemuda-pemudi serta masyarakat Indonesia berkat buah dari apa yang disajikan media sekuler melalui sinetron-sinetron, terutama sinema India dan korea yang turut menciptkan budaya matre (materialis). Namun pada hakikatnya ideologi materialisme berawal dari ideologi hedonisme, karena kedua gaya hidup tersebut tidak terlepas dari kenikmatan akan pemilikan materi dan fisik semata.

Itulah budaya-budaya yang merupakan hasil dari proses globalisasi industri budaya dengan dukungan media, yang umumnya berlangsung dari negara maju ke negara berkembang seperti Indonesia. Kapitalisme global yang berproses secara canggih lewat kedigjayaan teknologi komunikasi dan informasi global ternyata menciptakan semacam gambaran dunia kehidupan yang tersegimentasi. Bukankah melalui media juga cara hidup tengah di awasi, cara hidup yang dikontrol, cara hidup yang didiktekan dan dikendalikan daya-daya halus logika pasar global (Hedonisme, konsumerisme dan materialisme) lewat bujuk rayu iklan, lewat pesona kenikmatan hidup yang ditawarkan industri hiburan, sehingga menciptakan kemabukan akan pesona iklan dan industri budaya yang dangkal.

Karakter-karakter yang sudah tak mencerminkan budaya seorang pelajar. Karakter, yang benar-benar ingin menggeser karakter sesungguhnya dari pribadi seorang pelajar. Hal ini dapat di buktikan dengan media yang memunculkan idola-idola baru bagi pelajar, padahal samasama kita ketahui banyak dari mereka yang moralnya bobrok ditambah perilaku yang tidak mencerminkan keteladanan yang baik bagi pelajar. Keadaan seperti ini tentu tidak baik bagi perkembangan karakter pelajar. Kalau terus dibiarkan maka lama kelamaan bangsa Indonesia ini akan semakin kehilangan karakternya. Yang di lebih khawatirkan, yakni sudah tidak di akuinya keberadaan bangsa Indonesia ini oleh bangsa lain disebabkan sudah hilangnya jati diri bangsa Indonesia ini karena tergerus oleh arus media yang negatif.

Kesibukan orang tua juga menjadi faktor pendorong mudahnya media merasuki pemikiran pelajar. Kenapa demikian ?, karena di era modern yang di tuntut serba cepat ini menyebabkan kecil kemungkinan bagi para orang tua dalam berperan layaknya orang tua yang sesungguhnya. Banyak dari pelajar yang di telantarkan sendiri oleh orang tuanya. Akibatnya, para pelajar kemudian mencari orang tua yang lain yang bisa lebih banyak meluangkan waktunya untuk mereka. Hingga 
pada akhirnya medialah yang menggeser posisi orang tua dalam membentuk karakter pelajar. Kemajuan jaman dan teknologi memang tidak bisa lepas dari kehidupan sekarang. Bahkan seharusnya kemajuan peradaban ini bisa membuat para pelajar semakin berkarakter. Karena apabila dibandingkan dengan masa silam, pembentukan karakter masa kini terbilang lebih mudah dan berpengaruh. Hal ini karena pengaruh media yang besar, bahkan pengaruh media bisa mengalahkan pengaruh negara.

\section{Peran konselor dalam Mengantisipasi Krisis Moral Anak dan Remaja melalui Pemanfaatan Media "Baru"}

Pada konsep tradisional guru BK lebih berperan sebagai transformator artinya guru BK berperan hanya sebagai penyampai pesan dengan menggunakan komunikasi langsung (direct communication), pola ini membuat siswa kurang aktif hanya menerima materi BK saja, seperti halnya analogi gelas yang siap diisi air. Kondisi ini tidak sesuai dengan konsep bimbingan dan konseling. Bimbingan dan konseling memandang siswa sebagai individu yang aktif, memiliki kemampuan dan potensi yang perlu dieksplorasi secara optimal. Selain memandang penting peran aktif siswa, bimbingan dan konseling juga menuntut peran guru BK lebih luas. Di antara tugas guru BK tersebut adalah sebagai perancang program bimbingan dan konseling dalam kata lain mampu merancang program bimbingan dan konseling yang baik dan termasuk di dalamnya merancang media bimbingan dan konseling.

Suatu media bimbingan dan konseling dikatakan baik, bila media tersebut memiliki tingkat relevasi dengan tujuan BK, materi dan karakteristik siswa. Dilihat dari kewewenangan dalam bimbingan dan konseling, guru BK adalah orang yang paling menguasai materi, mengetahui tujuan apa yang mesti di buat dan mengenali betul kebutuhan siswanya. Dengan demikian, alangkah baiknya kalau media juga dibuat oleh guru BK, karena guru BK yang mengetahui secara pasti kebutuhan untuk bimbingan dan konselingnya, termasuk permasalahan-permasalahan yang dihadapi siswa. Di sinilah peran guru BK sebagai kreator yaitu menciptakan media yang tepat, efisisen dan menyenangkan bagi siswa (Nursalim, 2014).

Selanjutnya penggunaan media secara kreatif akan memperbesar kemungkinan bagi siswa/ klien untuk belajar lebih banyak, mencamkan apa yang dipelajarinya lebih baik, dan meningkatkan penampilan dalam melakukan keterampilan sesuai dengan yang menjadi tujuan bimbingan dan konseling.

Dalam kaitannya dengan fungsi media bimbingan dan konseling, dapat ditekankan beberapa hal berikut ini:

1. Penggunaan media bimbingan dan konseling bukan merupakan fungsi tambahan, tetapi memiliki fungsi tersendiri sebagai sarana bantu untuk mewujudkan situasi bimbingan dan konseling yang lebih efektif.

2. Media bimbingan dan konseling merupakan bagian integral dari keseluruhan proses layanan bimbingan dan konseling. Hal ini mengandung pengertian bahwa media bimbingan dan konseling sebagai salah satu komponen yang tidak berdiri sendiri tetapi saling berhubungan dengan komponen lainnya dalam rangka menciptakan situasi yang diharapkan.

3. Media bimbingan dan konseling dalam penggunaannya harus relevan dengan tujuan/ kompetensi yang ingin dicapai dan isi layanan bimbingan dan konseling itu sendiri. Fungsi ini mengandung makna bahwa penggunaan media dalam bimbingan dan konseling harus selalu melihat kepada kompetensi atau tujuan dan bahan atau materi bimbingan dan konseling.

4. Media bimbingan dan konseling bukan berfungsi sebagai alat hiburan, dengan demikian tidak diperkenankan menggunakannya hanya sekedar untuk permainan atau memancing perhatian siswa/ klien semata.

5. Media bimbingan dan konseling bisa berfungsi untuk memperlancar proses bimbingan dan konseling. Fungsi ini mengandung arti bahwa dengan media bimbingan dan konseling siswa dapat lebih mudah memahami masalah yang dialami atau menangkap bahan yang disajikan lebih mudah dan lebih cepat.

6. Media bimbingan dan konseling berfungsi untuk meningkatkan kualitas layanan bimbingan dan konseling. Pada umumnya hasil bimbingan dan konseling yang diperoleh siswa dengan menggunakan media bimbingan dan konseling akan tahan lama mengendap.

Terkait dengan hadirnya media baru, ada beberapa hal yang perlu dilakukan oleh guru BK, yaitu:

1. Guru BK perlu selalu meningkatkan kemampuan dan keterampilannya terkait dengan kehadiran media "baru".

2. Guru BK perlu bekerja sama dengan orang tua dalam memonitor penggunaan "media baru" oleh anak dan remaja, baik berupa frekuensi, durasi maupun isi media "baru".

3. Guru BK perlu bekerja sama dengan guru TIK, untuk mengedukasi siswa tentang penggunaan internet positif.

4. Guru BK perlu mengantisipasi munculnya berbagai masalah terkait adanya media "baru" diantaranya; kecanduan game onlie, pornografi, bullying dan sebagainya. 
5. Guru BK harus mampu memanfaatkan media "baru" untuk menunjang prencanaan, pelaksanaan dan penilaian layanan BK.

\section{PENUTUP}

\section{Simpulan}

Konselor sebagai salah satu elemen pendidikan yang berperan dalam menmbangun moral siswa. Perkembangan jaman tidak terlepas dari perkembangan teknologi yang turut serta membangun moral siswa. Perkembangan teknologi selayaknya menjadi media yang mampu membangun moral siswa kearah yang lebih baik. Beberapa peran yang dapat dilakukan konselor sekolah untuk mengantisipasi munculnya krisis moral pada anak dan remaja adalah; 1) meningkatkan kemampuan dan ketrampilan dalam memanfaatkan kehadiran "media baru", 2) bekerja sama dengan wali kelas dan orang tua dalam memonitor penggunaan media baru, baik berupa frekuensi, durasi maupun isi, 3) Mengedukasi penggunaan internet positif, 4) mempelajari strategi konseling untuk menangani masalah yang muncul diantaranya, kecanduan game onlie, pornografi, bullying dan ujaran kebencian.

\section{Saran}

Saran yang dapat diberikan oleh peneliti adalah bagi konselor dan pembaca idealnya mampu mengembangkan media baru lainnya yang berteknologi untuk membangun moral remaja.

\section{DAFTAR PUSTAKA}

AECT, 1997. Definisi Teknologi Pendidikan (Seri Teknologi Pendidikan No. 7). Jakarta. CV. Rajawali.

Baggerly, Jennifer. 2002. Practical Technological Applications to Promote Pedagogical Principles and Active Learning in Counselor Education. Journal of Technology in Counseling. Vol. 2_2.

Dryden, Gordon; dan Voss, Jeanette; (1999), "the Learning Revolution: to Change the Way the World Learn", the Learning Web, Torrence, USA, http://www.thelearningweb.net.

Gamble, and Gamble, 2005, Communication Works. New York: McGraw-Hill.

Hohenshill, Thomas, H. 2000. High Tech Counseling. Journal of Counseling and Development. V 78: 365368.

McQuil, Denis.1996, Teori Komunikasi Massa: Suatu Pengantar. Jakarta; Erlangga.

Nursalim, Mochamad. 2014. Pengembangan Media Bimbingan dan Konseling. Jakarta: Indeks.

Nursalim, Mochamad. 2014. Strategi dan Intervensi Konseling. Jakarta: Indeks.

Nursalim, Mochamad. 2015. Pengembangan Profesi Bimbingan dan Konseling. Jakarta: Erlangga.
Sampson, James, P. 2000. Using the Internet to Enchance Testing in Counseling. Journal of Counseling and Development. 5. 78: 348-356.

. Bandung: Remaja Rosdakarya. 